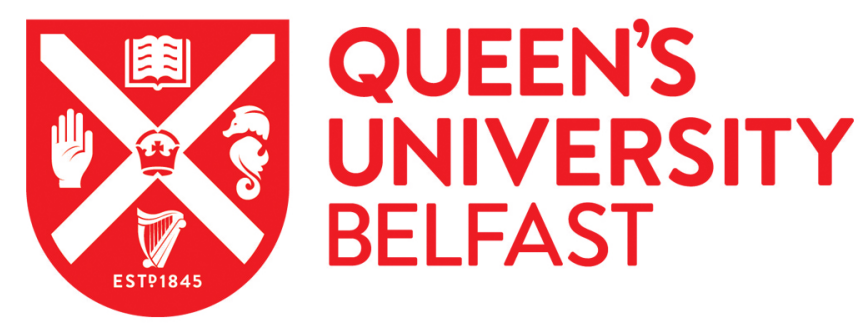

\title{
Development of an optimized broth enrichment culture medium for the isolation of Clostridium difficile
}

Connor, M. C., McGrath, J. W., McMullan, G., Marks, N., \& Fairley, D. J. (2018). Development of an optimized broth enrichment culture medium for the isolation of Clostridium difficile. Anaerobe, 54, 92-99.

https://doi.org/10.1016/j.anaerobe.2018.08.006

\section{Published in:}

Anaerobe

\section{Document Version:}

Peer reviewed version

Queen's University Belfast - Research Portal:

Link to publication record in Queen's University Belfast Research Portal

\section{Publisher rights}

Copyright 2018 Elsevier. This manuscript is distributed under a Creative Commons Attribution-NonCommercial-NoDerivs License

(https://creativecommons.org/licenses/by-nc-nd/4.0/), which permits distribution and reproduction for non-commercial purposes, provided the author and source are cited.

\section{General rights}

Copyright for the publications made accessible via the Queen's University Belfast Research Portal is retained by the author(s) and / or other copyright owners and it is a condition of accessing these publications that users recognise and abide by the legal requirements associated with these rights.

Take down policy

The Research Portal is Queen's institutional repository that provides access to Queen's research output. Every effort has been made to ensure that content in the Research Portal does not infringe any person's rights, or applicable UK laws. If you discover content in the Research Portal that you believe breaches copyright or violates any law, please contact openaccess@qub.ac.uk. 


\section{Accepted Manuscript}

Development of an optimized broth enrichment culture medium for the isolation of Clostridium difficile

Mairéad C. Connor, John W. McGrath, Geoff McMullan, Nikki Marks, Derek J.

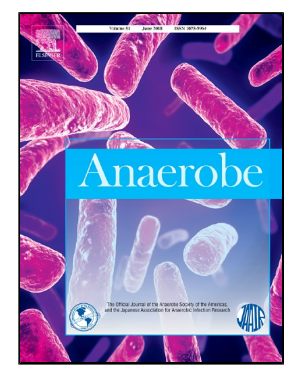
Fairley

PII: S1075-9964(18)30150-1

DOI: 10.1016/j.anaerobe.2018.08.006

Reference: YANAE 1936

To appear in:

Anaerobe

Received Date: 12 April 2018

Accepted Date: 13 August 2018

Please cite this article as: Mairéad C. Connor, John W. McGrath, Geoff McMullan, Nikki Marks, Derek J. Fairley, Development of an optimized broth enrichment culture medium for the isolation of Clostridium difficile, Anaerobe (2018), doi: 10.1016/j.anaerobe.2018.08.006

This is a PDF file of an unedited manuscript that has been accepted for publication. As a service to our customers we are providing this early version of the manuscript. The manuscript will undergo copyediting, typesetting, and review of the resulting proof before it is published in its final form. Please note that during the production process errors may be discovered which could affect the content, and all legal disclaimers that apply to the journal pertain. 


\section{Development of an optimized broth enrichment culture medium for the}

\section{2 isolation of Clostridium difficile}

3 Mairéad C. Connor*a, John W. McGratha, Geoff McMullanª, Nikki Marks ${ }^{a}$ and Derek

4 J. Fairleyb

a. School of Biological Sciences and the Institute for Global Food Security, Medical Biology Centre, Queens University Belfast, Northern Ireland.

b. Department of Microbiology, Belfast Health \& Social Care Trust, Belfast, Northern Ireland.

\section{${ }^{*}$ Corresponding author: School of Biological Sciences and the Institute for Global}

Food Security, Medical Biology Centre, Queens University Belfast, 97 Lisburn Road, Belfast, Northern Ireland, BT9 7BL; m.connor@qub.ac.uk.

\section{Abstract}

Clostridium difficile is a spore forming bacterium and the leading cause of colitis and antibiotic associated diarrhoea in the developed world. Effective recovery of spores, particularly in low numbers, is imperative to obtain accurate prevalence data, due to the low number of spores found within non-clinical samples $(<20 / \mathrm{ml})$. Through comparison of $C$. difficile enrichment media, this study showed the importance of selecting an effective enrichment media. Commonly used broths, such as Cooked Meat broth, promote significantly less growth than other available broths such as Brain Heart Infusion broth, $\mathrm{BHI}$. The optimization of $\mathrm{BHI}$ using selective antibiotics, moxalactam and norfloxacin, and sodium taurocholate at a concentration of $0.4 \%$, allowed for high growth rate $\left(0.465\right.$ hour $\left.^{-1}\right)$, short lag times $(<14$ hours $)$ and recovery 
of spores at low concentrations. The optimized broth, designated BHIMN-T, outperformed other commonly used broths so can be recommended for future studies.

Keywords: Clostridium difficile; Culture media; Growth; Taurocholate; Spores

\section{Introduction}

Clostridium difficile is a Gram positive, spore forming, anaerobic bacterium and a major cause of diarrhoea and pseudomembranous colitis $(1,2)$. Transmission and spread of $C$. difficile is facilitated by the resistance of $C$. difficile spores to harsh environmental conditions, for example, heat, cleaning and disinfectant agents along with alcohol based hand sanitizers (3-6). Spores of $C$. difficile can persist on surfaces for many months, providing a reservoir of infection in hospitals and community-care settings. It is increasingly evident that $C$. difficile inhabits a wider spectrum of environments, with toxigenic strains having been isolated from animals, foodstuffs, soil, water and wastewater treatment facilities (7-19). Spore burden in such nonclinical samples is often low: $<20$ spores/ml have been reported in food samples (20), while the infectious dose required to cause $C$. difficile infection (CDI) in mice from controlled surface contamination is estimated at $<7$ spores $/ \mathrm{cm}^{2}(21)$. Given the public health concern, $C$. difficile monitoring in non-clinical reservoirs is important to further our understanding of community-acquired $\operatorname{CDI}(22,23)$.

Central to such surveillance is the development of an effective isolation media. Based on Google Scholar citations (March 2018) the four most widely used formulations for C. difficile broth enrichment and growth are; Brain Heart Infusion broth (BHI: 5130 cites), Cooked Meat broth (CM: 4860 cites), Cycloserine Cefoxitin Fructose broth 
(CCFB: 964 cites) and C. difficile Moxalactam Norfloxacin broth (CDMN: 294 cites).

50 These, along with a relatively new broth - Clostridium difficile Brucella Broth with Lcystine and thioglycolic acid (CDBB-TC), referenced in one study - were selected as the basis of this investigation. Use of these basal media preparations is further complicated by the addition of various supplements. These include: a) antibiotics, added as a combination of either cefoxitin and cycloserine, or norfloxacin and moxalactam (24-26); b) sodium taurocholate and/or horse blood (26-29); and c) the use of thioglycolic acid and L-cystine in lieu of incubation within an anaerobic cabinet (30).

We report an evaluation of these media formulations for the recovery and growth of $C$. difficile, and development of an optimized enrichment media based on $\mathrm{BHI}$ broth supplemented with moxalactam $(32 \mu \mathrm{g} / \mathrm{ml})$, norfloxacin $(12 \mu \mathrm{g} / \mathrm{ml})$ and $0.4 \%(\mathrm{w} / \mathrm{v})$ sodium taurocholate (designated BHIMN-T). Use of BHIMN-T for the recovery of $C$. difficile M120 spores resulted in a 10 hour decrease in the lag phase and a $55 \%$ increase in growth rate when compared to other published media preparations.

\section{Materials and methods}

\subsection{Preparation of spore suspension}

Spore suspensions of representative isolates from $C$. difficile clades 1-5 were prepared: - TL178 (Clade 1, Ribotype 002); R20291 (Clade 2, Ribotype 027); CD305 (Clade 3, Ribotype 023); CF5 (Clade 4, Ribotype 017) and M120 (Clade 5, Ribotype 078), from isolates obtained from the archives at the Kelvin Laboratories, Royal Victoria Hospital, Belfast, Northern Ireland.

Fastidious anaerobe blood agar (FAABL) (Oxoid, Basingstoke, UK) was inoculated with $C$. difficile $\mathrm{M} 120$ and incubated anaerobically $\left(\mathrm{N}_{2} / \mathrm{CO}_{2} / \mathrm{H}_{2}\right)$ at $37^{\circ} \mathrm{C}$ for $72 \mathrm{~h}$ in an 
74

anaerobic chamber (Don Whitley Scientific, Shipley, UK). To inactivate vegetative cells, colonies were suspended in $5 \mathrm{ml}$ sterile Phosphate Buffered Saline (PBS) and subjected to alcohol shock ( $5 \mathrm{ml}$ of absolute ethanol added to $5 \mathrm{ml}$ suspension) for 1 hour to kill vegetative cells, in accordance with the spore culture method of UK Standards for Microbiology Investigations (31). Alcohol shocked suspensions were centrifuged at 3,000 $\mathrm{xg}$ for $4 \mathrm{~min}$ and washed once in $5 \mathrm{ml}$ sterile PBS with the resultant pellet resuspended in $70 \%(\mathrm{v} / \mathrm{v})$ ethanol. Spore stock concentrations were determined by viable spore counts (32). Spore stock was stored in $50 \mu$ l aliquots at $-20^{\circ} \mathrm{C}$.

\subsection{Preparation of enrichment media}

Enrichment media were prepared as follows. All products were supplied by Sigma Aldrich, UK, unless otherwise stated.

Brain Heart Infusion broth (BHI) (Oxoid, Basingstoke, UK). Lyophilised media (3.7\% [w/v]) which contained, per litre; brain infusion solids $(12.5 \mathrm{~g})$, beef heart infusion solids $(5.0 \mathrm{~g})$, proteose peptone $(10.0 \mathrm{~g})$, glucose $(2.0 \mathrm{~g})$, sodium chloride $(5.0 \mathrm{~g})$ and disodium phosphate $(2.5 \mathrm{~g})$.

C. difficile broth supplemented with Moxalactam and Norfloxacin (CDMN) was prepared in accordance with Xu et al (17) and contained, per litre; proteose peptone $(40.0 \mathrm{~g})$, disodium hydrogen phosphate $(5.0 \mathrm{~g})$, potassium dihydrogen phosphate $(1.0$ $\mathrm{g})$, magnesium sulphate $(0.1 \mathrm{~g})$, sodium chloride $(2.0 \mathrm{~g})$, fructose $(6.0 \mathrm{~g})$ and CDMN supplement (Oxoid, Basingstoke , UK); cysteine hydrochloride (500.0mg), norfloxacin (12.0 mg), moxalactam (32.0 mg) was added post sterilisation. 
98 Cycloserine Cefoxitin Fructose Broth (CCFB) was prepared as described by Arroyo et al. (25) and contained, per litre; proteose peptone $(40.0 \mathrm{~g})$, disodium hydrogen phosphate $(5.0 \mathrm{~g})$, potassium dihydrogen phosphate $(1.0 \mathrm{~g})$, magnesium sulphate $(0.1$

102 Basingstoke, UK), cefoxitin (8.0 mg) (Oxoid, Basingstoke, UK) and defibrinated horse

103 blood (70.0 ml) (Lab Supplies Ltd, Antrim, UK) were added post sterilisation.

C. difficile Brucella Broth with thioglycolic acid and L-cysteine (CDBB-TC) was prepared according to Cadnum et al. (30) and contained, per litre; Brucella broth (28.0 g), vitamin $\mathrm{K} 1$ solution $(1.0 \mathrm{mg})$, hemin solution $(5.0 \mathrm{mg})$ (Fisher Scientific,

108 Loughborough, UK), sodium bicarbonate $(0.1 \mathrm{~g})$, D-mannitol $(6.0 \mathrm{~g})$. Neutral red solution $(1 \%[\mathrm{v} / \mathrm{v}])(5.0 \mathrm{ml})$, sodium taurocholate $(0.5 \mathrm{~g})$, lysozyme $(5.0 \mathrm{mg})($ Fisher

110 Scientific, Loughborough, UK), D-cycloserine (500.0 mg), cefoxitin (16.0 mg), agar

111 (1.0 g), thioglycolic acid (1.0 g) and L-cystine (1.0 g) (Fisher Scientific, Loughborough,

112 UK) were added post sterilisation.

114 Cooked meat broth (CM) (Oxoid, Basingstoke, UK). CM was purchased as a pre115 prepared media, which contained, per litre; heart muscle (454.0 g), peptone (10.0 g),

116 Lab-Lemco powder $(10.0 \mathrm{~g})$, sodium chloride $(5.0 \mathrm{~g})$ and glucose $(2.0 \mathrm{~g})$.

\section{$118 \quad 2.3$ Growth of C. difficile M120}

119 Broths $(5 \mathrm{ml})$ were aliquoted into sterile $30 \mathrm{ml}$ polystyrene screw cap universals 120 (Medline Scientific, Chalgrove, UK) and pre-reduced for 5 hours in an anaerobic 121 chamber prior to inoculation. The pre-reduced broths were inoculated to a 122 concentration of $2 \%(\mathrm{v} / \mathrm{v})$ spore inoculum, under anaerobic conditions, by centrifuging 
$123100 \mu \mathrm{l}$ of spore suspension at $14,000 \mathrm{xg}$ for $5 \mathrm{~min}$. Inocula were subsequently prepared by resuspension of the spore pellet in $100 \mu \mathrm{l}$ of the appropriate enrichment broth. Triplicate growth assays were carried out for each broth.

\section{Determination of growth rate via $q P C R$}

128 Growth rate of $C$. difficile M120 in each media variant was determined via real-time quantitative PCR using a method modified from Nadkarni et al. (33). For media which did not contain defibrinated horse blood, DNA was extracted according to Stubbs et

131 al. whereby $100 \mu \mathrm{l}$ of culture was boiled in $300 \mu \mathrm{l}$ of sterile water containing $5 \%(\mathrm{w} / \mathrm{v})$

132 Chelex-100 (Sigma-Aldrich, Irvine, UK) for 5 min (34). For media which did contain 133 defibrinated horse blood, DNA was extracted and purified using the DNA/Viral Kit on 134 the MagNA Pure 96 extraction platform (Roche Applied Science, Penzberg, Germany) 135 in accordance with the manufacturer's instructions. A previously described method to 136 monitor bacterial load (growth) using real-time PCR (33) was adapted for this study

137 using an assay targeting the $C$. difficile toxin B gene, $t c d B$. Assays were performed on 138 a LightCycler 480 (Roche Applied Science, Penzberg, Germany) using the TaqMan® 139 primer and probe set of Luna et al. (35) tcdB_F - GAAAGTCCAAGTTTACGCTCAAT; 140 tcdB_R - GCTGCACCTAAACTTACACCA; tcdB_TM- FAM 141 ACAGATGCAGCCAAAGTTGTTGAATT-TAMRA. Unless otherwise specified all 142 reagents were supplied by Invitrogen Ltd (Paisley, UK). Each reaction contained; 1x 143 Platinum ${ }^{\circledR}$ Quantitative PCR SuperMix-UDG, Nuclease Free Water (Sigma Aldrich, 144 Irvine, UK), Bovine Serum Albumin $(0.2 \mu \mathrm{g} / \mathrm{ml})$ (Sigma Aldrich, Irvine, UK), $\mathrm{MgCl}_{2}$ (3 $145 \mathrm{mM}), \mathrm{tcdB} \_\mathrm{F}(0.4 \mu \mathrm{M}), \mathrm{tcdB} \_\mathrm{R}(0.4 \mu \mathrm{M})$ and tcdB_TM $(0.2 \mu \mathrm{M})$. 
146 For each assay, $2 \mu \mathrm{l}$ of template DNA was added to $8 \mu \mathrm{l}$ of Mastermix, giving a final

147 reaction volume of $10 \mu \mathrm{l}$. Reactions were cycled using the following conditions: $50^{\circ} \mathrm{C}$

148 for $2 \mathrm{~min}, 1$ cycle of $95^{\circ} \mathrm{C}$ for $5 \mathrm{~min}, 45$ cycles of $95^{\circ} \mathrm{C}$ for $10 \mathrm{~min}, 57^{\circ} \mathrm{C}$ for $20 \mathrm{sec}$, and

$14972^{\circ} \mathrm{C}$ for $10 \mathrm{sec}$.

150 Purified and quantified C. difficile M120 DNA was used for calibration of qPCR, using duplicate 10 -fold serial dilutions of DNA in $0.1 x$ Tris EDTA with yeast tRNA $(10 \mu \mathrm{g} / \mathrm{ml})$

152 (Thermo Scientific, Leicestershire, UK). The $t c d B$ qPCR was run for each dilution in

153 triplicate over a 6-log range (calibration $\mathrm{R}^{2}=9.78$ ). Calibrators were tested alongside

154 extracts from growth assay samples and specific growth rates calculated from qPCR 155 copy numbers.

\section{$157 \quad 2.4$ Optimization of BHI}

\section{$158 \quad$ Antibiotic supplementation of $\mathrm{BHI}$}

159 The effect of supplementing BHI media with moxalactam $(32 \mu \mathrm{g} / \mathrm{ml})$ and norfloxacin

$160(12 \mu \mathrm{g} / \mathrm{ml})$, designated BHIMN, was assessed by comparison of $C$. difficile M120 161 growth in $\mathrm{BHI}$ without antibiotic addition. Moxalactam and norfloxacin have been 162 reported to provide a higher degree of selectivity than the other commonly used 163 antibiotic supplements, cycloserine and cefoxitin (26). BHIMN media $(n=3)$ was prepared by addition of moxalactam and norfloxacin selective supplement containing cysteine hydrochloride $(500.0 \mu \mathrm{g} / \mathrm{ml})$, norfloxacin $(12.0 \mu \mathrm{g} / \mathrm{ml})$, and moxalactam $(32.0$

$166 \mu \mathrm{g} / \mathrm{ml})$ (Oxoid, Basingstoke, U.K) to $\mathrm{BHI}(\mathrm{n}=3)$. All media was pre-reduced for 5 hours 167 prior to growth assays. 
170 The effect of sodium taurocholate concentration on growth of $C$. difficile M120 in

171 BHIMN was investigated. It is known that the secondary bile salt deoxycholate, formed

172 through metabolism of sodium taurocholate, inhibits vegetative cell growth, therefore

173 a range of sodium taurocholate concentrations $(0-1 \%[\mathrm{w} / \mathrm{v}])$ were investigated with

174 regard to optimal growth of $C$. difficile M120.

175 Sodium taurocholate was added to final concentrations $(\mathrm{w} / \mathrm{v})$ of $0.1 \%, 0.2 \%, 0.3 \%$,

$1760.4 \%, 0.5 \%$ or $1 \%$. Replicate growth assays $(n=12)$ of $C$. difficile M120 in pre-reduced

177 BHIMN at each sodium taurocholate concentration were carried out under anaerobic conditions in microtitre plates at $37^{\circ} \mathrm{C}$ with growth compared to that of a sodium taurocholate free control. Broths, with a total volume of $200 \mu \mathrm{l}$ per well, were inoculated to a concentration of $2 \%(\mathrm{v} / \mathrm{v})$ inoculum. Growth was assessed by determining optical

181 density at 600nm using a FLUOstar Omega Microplate reader (BMG Labtech, 182 Ortenberg, Germany).

\section{Effect of horse blood}

185 BHIMN was augmented with defibrinated horse blood to final concentrations (v/v) of $1861 \%, 2 \%, 3 \% .5 \%$ or $7 \%$. Broths $(5 \mathrm{ml})$ were inoculated to a concentration of $2 \%(\mathrm{v} / \mathrm{v})$

187 inoculum. Growth assays of $C$. difficile M120 in BHIMN at each horse blood concentration were carried out, in triplicate, under anaerobic conditions at $37^{\circ} \mathrm{C}$ with growth compared to that of a horse blood free control. As broth containing horse blood

190 is opaque, growth could not be measured using optical density therefore growth 191 assays used real-time PCR as described. 
193 Addition of blood to growth media may hinder bacterial growth due to the bactericidal

194 components naturally occurring within blood, such as complement (36). Heat

195 treatment inactivates the complement system without affecting the nutritional value of

196 the blood (36). A $10 \mathrm{ml}$ aliquot of horse blood was heated at $56^{\circ} \mathrm{C}$ for a total of $30 \mathrm{~min}$,

197 with mixing every $5 \mathrm{~min}$, and then transferred to ice to cool immediately (37). Once

198 cooled, it was added to BHIMN and reduced prior growth assay. Pre-reduced BHIMN-

199 HB supplemented with untreated horse blood from the same batch was used as a 200 control.

\subsection{Comparison of commonly used media}

203 The optimized media (designated BHIMN-T) was compared to CCFB and CDMN using

204 the supplements described in Table 1. Pre-reduced broths $(5 \mathrm{ml})$ were inoculated to a concentration of $2 \%(\mathrm{v} / \mathrm{v})$ inoculum. Growth assays in each broth were completed in triplicate of $C$. difficile M120 in each broth variant were carried out under anaerobic conditions at $37^{\circ} \mathrm{C}$ and growth was determined using real-time PCR as described.

\subsection{Evaluation of spore recovery in BHIMN-T}

210 In order to confirm BHIMN-T was effective for recovery across genetically diverse $C$.

211 difficile isolates, spore recovery using the optimal BHIMN-T broth was assessed over

212 a range of spore concentrations from representative isolates from clades $1-5$ of $C$.

213 difficile. Serial dilutions of spore suspension were prepared in sterile PBS. Pre-

214 reduced BHIMN-T was aliquoted into a microtitre plate, $200 \mu \mathrm{l} /$ well, within an

215 anaerobic chamber. Replicate wells $(n=14)$ were inoculated with appropriate dilution 
216 to achieve target spore number $\left(\mathbf{1 0}^{-4}: 130\right.$ spores $\pm 3 ; 10^{-5}: 13$ spores $\pm 0.3 ; 10^{-6}: 1.3$

$217 \pm 0.03$ ) and incubated anaerobically for 24 hours. Positive growth was determined by

218 visible growth in the microtitre plate and the results were evaluated using the Most

219 Probable Number (MPN) method (38), to estimate the MPN/ml and assess ability of

220 BHIMN-T to recover spores across a range of inoculum concentrations.

\subsection{Statistical Analysis}

All statistical analyses were carried out using GraphPad Prism v5 (GraphPad

Software Inc.). A One-Way Analysis of Variance (ANOVA) was employed to

determine significant differences in growth rate obtained by C. difficile M120 in each

broth. Statistical significance was determined at $p<0.05$.

MPN/ml and corresponding 95\% confidence limits were estimated using the standard MPN method, approved by the US Food and Drug Administration (FDA) (38). Each dilution was subject to 14 replicates.

\section{Results and Discussion}

\subsection{Evaluation of enrichment media}

233 Growth of $C$. difficile M120 was assessed in five different broth enrichment culture

234 media. The results show highest growth rate in non-selective BHI broth $(0.202 \pm 0.045$

235 hour $^{-1}$ ) compared to CCFB, CDMN, CDBB-TC and CM (Figure 1). CCFB and CDMN 236 are similar selective media, both consisting of a fructose base $(17,25)$. CCFB is 237 however augmented with the antibiotics cycloserine $(250 \mu \mathrm{g} / \mathrm{ml})$ and cefoxitin (8 $238 \mu \mathrm{g} / \mathrm{ml}$ ), and defibrinated horse blood (7\% [v/v]); CDMN is supplemented with the 
239 antibiotics moxalactam $(32 \mu \mathrm{g} / \mathrm{ml})$ and norfloxacin $(12 \mu \mathrm{g} / \mathrm{ml})$. Both CCFB and CDMN

240 are equally effective for growth of $C$. difficile M120. No significant difference in C.

241 difficile M120 growth rate was observed between these media, with growth rates of

$2420.10 \pm 0.030$ hour $^{-1}$ and $0.08 \pm 0.021$ hour $^{-1}$, respectively.

243 The growth rates observed in CM and CDBB-TC were significantly less than that of 244 the other broths $(p<0.001)$. CDBB-TC is a recently described culture medium for the 245 growth of $C$. difficile without the need for strict anaerobic incubation (30). No growth

246 was observed in CDBB-TC, with or without $0.1 \%[\mathrm{w} / \mathrm{v}]$ sodium taurocholate addition,

247 under either anaerobic or aerobic conditions. Cadnum et al. have however reported

248 the successful growth of $C$. difficile from a range of environmental samples using this

249 formulation (30). CM provided a growth rate of $0.017 \pm 0.003$ hour $^{-1}$, which was 250 significantly lower than CCFB $(0.10 \pm 0.030$ hour $)$, CDMN $\left(0.08 \pm 0.021\right.$ hour $\left.^{-1}\right)$ and $251 \mathrm{BHI}\left(0.202 \pm 0.045\right.$ hour $\left.^{-1}\right)$. The CM and CDBB-TC media combinations were not 252 considered further in this study. Studies using these media might be at risk from false 253 negatives (Figure 1) $(30,39)$.

\subsection{Optimization of BHI}

Addition of antibiotics: moxalactam and norfloxacin

257 In initial studies BHI outperformed the other media (Figure 1) although this medium is 258 non-selective for $C$. difficile. Moxalactam $(32 \mu \mathrm{g} / \mathrm{ml})$ and norfloxacin $(12 \mu \mathrm{g} / \mathrm{ml})$ have been shown to provide higher selectivity when isolating $C$. difficile when compared to cycloserine $(250 \mu \mathrm{g} / \mathrm{ml})$ and cefoxitin $(8 \mu \mathrm{g} / \mathrm{ml})(26,40)$. BHI medium was therefore

261 supplemented with moxalactam $(32 \mu \mathrm{g} / \mathrm{ml})$ and norfloxacin $(12 \mu \mathrm{g} / \mathrm{ml})$, and designated 
as BHIMN. No significant difference was found in C. difficile M120 growth rate between

$\mathrm{BHI}$ and $\mathrm{BHIMN}$ media (Figure 2) so BHIMN replaced $\mathrm{BHI}$ in subsequent studies.

\section{Addition of sodium taurocholate and defibrinated horse blood to BHIMN broth}

266 To determine if sodium taurocholate enhanced growth of $C$. difficile in BHIMN, growth assays were carried out in the presence of varying concentrations of sodium taurocholate $(0-1 \%[\mathrm{w} / \mathrm{v}]$ : Figure 3$)$. Previous studies have suggested that sodium taurocholate should be supplemented to a concentration of $0.1 \%(w / v)$ in $C$. difficile growth media $(17,25,30,41)$. In this study, a concentration of $0.4 \%$ was found to be most effective for promoting the growth of C. difficile M120 in BHIMN (Figure 3): 0.4\% sodium taurocholate provided significantly faster growth than $0.1 \%(p<0.001), 0.2 \%$ $(p<0.001), 0.3 \%(p<0.05), 0.5 \%(p<0.001)$ and $1 \%(p<0.0001)$, respectively (Figure 3).

Additionally, BHIMN broth supplemented with horse blood $(0-7 \%[\mathrm{v} / \mathrm{v}])$ showed no significant increase in the growth of C. difficile M120 (Figure 3; p>0.05): In other

277 publications, horse blood supplementation is recommended at $7 \%(\mathrm{v} / \mathrm{v})(25,26)$. Although horse blood does appear to enhance growth of $C$. difficile in certain

279 circumstances, e.g. growth of $C$. difficile on CCFB (26). It has also been suggested 280 that the addition of blood may hinder bacterial growth due to the bactericidal components, such as complement, naturally occurring within blood (36). In this study, no significant difference was observed in C. difficile M120 growth rate between BHIMN supplemented with defibrinated horse blood and complement inactivated BHIMN

284 horse blood broth, Figure $4(E)$ and Figure $4(F)$. Inactivation of the complement 
system within the blood did not improve growth of C. difficile M120 in BHIMN (Figure 4).

287 This study thus found that BHI supplemented with moxalactam $(32 \mu \mathrm{g} / \mathrm{ml})$, norfloxacin $(12 \mu \mathrm{g} / \mathrm{ml})$ and sodium taurocholate $(0.4 \%[\mathrm{w} / \mathrm{v}])$, designated as BHIMN-T, provided optimal growth of $C$. difficile M120 from spores.

\subsection{Comparison of commonly used media and BHIMN-T}

292 Growth in BHIMN-T was compared with CCFB and CDMN. A number of variations of

293 CCFB and CDMN have been reported in the literature, including the addition of defibrinated horse blood (HB) to CDMN (CCFB contains horse blood as prepared) and sodium taurocholate $(\mathrm{T})$ to both $(17,25,26,45)$. BHIMN-T was thus not only compared to CCFB and CDMN but also to their defibrinated horse blood (HB) and sodium

297 taurocholate (T) supplemented variants: These are designated as CCFB-T, CDMN-T,

298 CDMN-HB and CDMN-THB respectively (Table 1). The most effective broth for growth of $C$. difficile $\mathrm{M} 120$ was $\mathrm{BHIMN}-\mathrm{T}$, with a growth rate of 0.4645 hour $^{-1}$ and a lag phase of less than 14 hours (Table 2). Notably, including this optimal concentration of sodium taurocholate more than doubled the observed growth rate. Growth in BHIMN-T outperformed both CCFB and CDMN, with and without their recommended horse blood and sodium taurocholate supplementation (Figure 5); CCFB-T $(p<0.05)$, CDMN-HB $(p<0.01)$, CDMNT $(p<0.01)$, CDMN-THB $(p<0.001)$, CCFB $(p<0.001)$ and CDMN $(p<0.001)$ (Figure 5). All broths containing sodium taurocholate provided shorter lag

306 times (Table 2), most likely due to promotion of spore germination $(27,28,41)$.

307 Dharmasena and Jiang (2018) found BHI broth supplemented with $0.5 \%$ yeast extract, $308 \quad 0.1 \%$ L-cysteine, $0.1 \%$ sodium taurocholate, moxalactam (32 mg/l) and norfloxacin (12 
$309 \mathrm{mg} / \mathrm{l}$ ) proved to be the most effective broth in their study for recovery of $C$. difficile from

310 spiked compost (40). Their study did not however evaluate media containing sodium

311 taurocholate concentrations above $0.1 \%(\mathrm{w} / \mathrm{v})$, well below the $0.4 \%(\mathrm{w} / \mathrm{v})$ level shown

312 to be optimal in this study. They also found moxalactam and norfloxacin were a more

313 effective selective supplement than cycloserine and cefoxitin (40).

314 The addition of horse blood to $C$. difficile growth media is common practice $(46,47)$.

315 Horse blood improved the growth of $C$. difficile M120 in CDMN (Figure 5), however it

316 had no effect on growth rate across the varying concentrations tested in BHIMN

317 (Figure 3). The reason for this is unknown. BHI base may already provide optimal

318 growth nutrients for $C$. difficile growth. We note that broths containing horse blood are

319 less attractive due to their expense, short shelf life and ease of contamination associated with blood products (48).

\subsection{Evaluation of spore recovery using BHIMN-T}

BHIMN-T was assessed for both its effectiveness and efficiency in promoting spore recovery across clades $1-5$ of $C$. difficile, particularly from samples containing low spore numbers $(<20$ spores $/ \mathrm{ml})$ ]. Using spore suspensions prepared from representative isolates across a range of spore concentrations [where each $1 \times 10^{-5}$ dilution is representative of $13 \pm 0.3$ spores $/ \mathrm{ml}$ : Table 3 ), spores were recovered from each clade tested, and at each dilution (Table 3). No growth was however observed in BHIMN without sodium taurocholate supplementation at spore concentrations less

330 than $130 \pm 0.3$ spores/ml (Table 3 ). In spore suspensions $\geq 130$ spores $/ \mathrm{ml} \mathrm{BHIMN-T}$

331 recovered a median of 12.5 times more spores across the isolates tested (range 9.5 
332 - 13.1 times: Table 3) than BHIMN alone (estimated using the Most Probable Number

333 (MPN) method (38)] .

334 Lister et al. (2014) have previously reported that direct plating on Cycloserine-Cefoxitin

335 Egg Yolk agar, rather than broth enrichment, increases C. difficile spore recovery.

336 Using a semi-quantitative plate streaking approach Cycloserine-Cefoxitin Egg Yolk agar recovered $1 \times 10^{2}$ spores: no recovery was observed at $1 \times 10^{1}$ spores $/ \mathrm{ml}(49) \mathrm{cf}$. BHIMN-T (Table 3).

\section{Conclusion}

341 Given the increasing evidence that $C$. difficile spores reside in a much wider spectrum

342 of environments than hospitals and community care settings $(17,24,50-53)$, the

343 monitoring of potential infection reservoirs is essential to understand its spread. A

344 number of different media formulations have been described for $C$. difficile enrichment yet few studies compare their efficacy.

346 To develop an optimal broth medium for recovering C. difficile from clinical and non-

347 clinical samples, a number of factors must be considered. Firstly, high growth rate and

348 short lag times are desirable. Secondly, ease of preparation, shelf-life and complexity

349 must be considered. A number of published media, such as CDBB-TC, are complex

350 to prepare and contain ingredients which may not be readily available, whilst others,

351 based on for example horse blood, have short shelf-lives.

352 In this paper we describe the development of an improved media, designated BHIMN-

$353 \mathrm{~T}$, for the growth of $C$. difficile which combines ease of preparation and longer shelf

354 life (due to absence of horse blood), with high growth rates (0.465 hour-1), short lag 
355 times (<14 hours). Furthermore, BHIMN-T proved effective for the recovery of spores

356 at low concentrations, across a number of genetically diverse $C$. difficile isolates (Table $3573)$.

359 This study highlights the need for optimal methods for isolation of $C$. difficile, especially

360 from environmental and other non-clinical samples. Use of suboptimal culture methods can result in false negatives leading to skewed prevalence data (54), which may hinder attempts to track and prevent spread of $C$. difficile and its ubiquitous spores.

\section{Acknowledgements}

365 This work was supported by the Department for Employment and Learning, Northern Ireland. The authors are thankful to N.E. Vardy (Queen's University Belfast) for technical assistance provided.

\section{References}

370 1. Gerding DN, Johnson S, Peterson LR, Mulligan ME, Silva J. 1995. Clostridium difficile-associated diarrhea and colitis. Infect Control Hosp Epidemiol. 16:459477. PMID: 7594392

2. Fordtran JS. 2006. Colitis due to Clostridium difficile toxins: underdiagnosed, highly virulent, and nosocomial. Proc (Bayl Univ Med Cent) 19:3-12. PMID: 16424922

3. Rodriguez-Palacios A, LeJeune JT. 2011. Moist-heat resistance, spore aging, and superdormancy in Clostridium difficile. Appl Environ Microbiol 77:30853091. DOI: 10.1128/AEM.01589-10

4. Abreu AC, Tavares RR, Borges A, Mergulhão F, Simões M. 2013. Current and 
emergent strategies for disinfection of hospital environments. J Antimicrob Chemother 68:2718-2732. DOI: 10.1093/jac/dkt281

5. Speight S, Moy A, Macken S, Chitnis R, Hoffman PN, Davies A, Bennett A,

Walker JT. 2011. Evaluation of the sporicidal activity of different chemical disinfectants used in hospitals against Clostridium difficile. J Hosp Infect 79:18-22. DOI: 10.1016/j.jhin.2011.05.016

6. Vonberg RP, Kuijper EJ, Wilcox MH, Barbut F, Tüll P, Gastmeier P, Van Den Broek PJ, Colville A, Coignard B, Daha T, Debast S, Duerden BI, van den Hof

S, van der Kooi T, Maarleveld HJH, Nagy E, Notermans DW, O’Driscoll J, Patel B, Stone S, Wiuff C. 2008. Infection control measures to limit the spread of Clostridium difficile. Clin Microbiol Infect 14:2-20. DOI: 10.1111/j.14690691.2008.01992.x

7. Uzal FA, Diab SS, Blanchard P, Moore J, Anthenill L, Shahriar F, Garcia JP, Songer JG. 2012. Clostridium perfringens type C and Clostridium difficile coinfection in foals. Vet Microbiol 156:395-402. DOI: 10.1016/j.vetmic.2011.11.023

8. Cooper KK, Songer JG, Uzal F a. 2013. Diagnosing clostridial enteric disease in poultry. J Vet Diagn Invest 25:314-27. DOI: 10.1177/1040638713483468

9. Perkins SE, Fox JG, Taylor NS, Green DL, Lipman NS. 1995. Detection of Clostridium difficile toxins from the small intestine and cecum of rabbits with naturally acquired enterotoxemia. Lab Anim Sci 45:379-384. PMID: 7474876

10. Jones M, Hunter D. 1983. Isolation of Clostridium difficile from pigs. Vet Rec 112:253-253. PMID: 6845597

11. Lund BM, Peck MW. 2015. A possible route for foodborne transmission of Clostridium difficile? Foodborne Pathog Dis 12:177-82. DOI: 
10.1089/fpd.2014.1842

406

407

408

409

410

411

412

413

414

415

416

417

418

419

420

421

422

423

424

425

426

427

428

429

12. Marsh JW, Tulenko MM, Shutt KA, Thompson AD, Weese JS, Songer JG, Limbago BM, Harrison LH. 2011. Multi-locus variable number tandem repeat analysis for investigation of the genetic association of Clostridium difficile isolates from food, food animals and humans. Anaerobe 17:156-160. DOI: 10.1016/j.anaerobe.2011.05.015

13. Weese JS. 2010. Clostridium difficile in food - innocent bystander or serious threat? Clin Microbiol Infect 16:3-10. DOI: 10.1111/j.1469-0691.2009.03108.x

14. Songer JG, Trinh HT, Killgore GE, Thompson AD, McDonald LC, Limbago BM. 2009. Clostridium difficile in retail meat products, USA, 2007. Emerg Infect Dis 15:819-821. DOI: 10.3201/eid1505.081071

15. Rodriguez-Palacios A, Staempfli HR, Duffield T, Weese JS. 2007. Clostridium difficile in retail ground meat, Canada. Emerg Infect Dis 13:485-487. DOI: 10.3201/eid1303.060988

16. Janezic S, Potocnik M, Zidaric V, Rupnik M. 2016. Highly divergent Clostridium difficile strains isolated from the environment. PLoS One 11:1-12. DOI: 10.1371/journal.pone.0167101

17. Xu C, Weese JS, Flemming C, Odumeru J, Warriner K. 2014. Fate of Clostridium difficile during wastewater treatment and incidence in Southern Ontario watersheds. J Appl Microbiol 117:891-904. DOI: 10.1111/jam.12575

18. Nikaeen M, Aghili Dehnavi H, Hssanzadeh A, Jalali M. 2015. Occurrence of Clostridium difficile in two types of wastewater treatment plants. J Formos Med Assoc 114:663-665. DOI: 10.1016/j.jfma.2014.12.005

19. Romano V, Pasquale V, Krovacek K, Mauri F, Demarta A, Dumontet S. 2012. Toxigenic Clostridium difficile PCR ribotypes from wastewater treatment plants 
in Southern Switzerland. Appl Environ Microbiol 78:6643-6646. DOI: 10.1128/AEM.01379-12

20. Weese JS, Avery BP, Rousseau J, Reid-Smith RJ. 2009. Detection and enumeration of Clostridium difficile spores in retail beef and pork. Appl Environ Microbiol 75:5009-5011. DOI: 10.1128/AEM.00480-09

21. Lawley TD, Croucher NJ, Yu L, Clare S, Sebaihia M, Goulding D, Pickard DJ, Parkhill J, Choudhary J, Dougan G. 2009. Proteomic and genomic characterization of highly infectious Clostridium difficile 630 spores. J Bacteriol 191:5377-5386. DOI: 10.1128/JB.00597-09

22. Gupta A, Khanna S. 2014. Community-acquired Clostridium difficile infection: An increasing public health threat. Infect Drug Resist 7:63-72. DOI: 10.2147/IDR.S46780

23. Chitnis AS, Holzbauer SM, Belflower RM, Winston LG, Bamberg WM, Lyons C, Farley MM, Dumyati GK, Wilson LE, Beldavs ZG, Dunn JR, Gould LH, MacCannell DR, Gerding DN, McDonald LC, Lessa FC. 2013. Epidemiology of community-associated Clostridium difficile infection, 2009 through 2011. JAMA Intern Med 173:1359-1367. DOI: 10.1001/jamainternmed.2013.7056.

24. Alam MJ, Anu A, Walk ST, Garey KW. 2014. Investigation of potentially pathogenic Clostridium difficile contamination in household environs. Anaerobe 27:31-33. DOI: 10.1016/j.anaerobe.2014.03.002

25. Arroyo LG, Rousseau J, Willey BM, Don E, Staempfli, H., Mcgeer A, Weese JS, Low DE. 2005. Use of a Selective Enrichment Broth To Recover Clostridium difficile from Stool Swabs Stored under Different Conditions. J Clin Microbiol 43:5341-5343. DOI: 10.1128/JCM.43.10.5341-5343.2005

26. Aspinall ST, Hutchinson DN. 1992. New selective medium for isolating 
Clostridium difficile from faeces. J Clin Pathol 45:812-814. PMID: 1401214

456

457

458

459

460

461

462

463

464

465

466

467

468

469

470

471

472

473

474

475

476

477

478

479

27. Buggy BP, Hawkins CC, Fekety R. 1985. Effect of adding sodium taurocholate to selective media on the recovery of Clostridium difficile from environmental surfaces. Microbiology 21:636-638. PMID: 3988904

28. Blanco JL, Álvarez-Pérez S, García ME. 2013. Is the prevalence of Clostridium difficile in animals underestimated? Vet J 197:694-698. DOI: 10.1016/j.tvjl.2013.03.053

29. Marler LM, Siders JA, Wolters LC, Pettigrew Y, Skitt BL, Allen SD. 1992.

Comparison of five cultural procedures for isolation of Clostridium difficile from stools. J Clin Microbiol 30:514-516. PMID: 1537928

30. Cadnum JL, Hurless KN, Deshpande A, Nerandzic MM, Kundrapu S, Donskey CJ. 2014. Sensitive and selective culture medium for detection of environmental Clostridium difficile isolates without requirement for anaerobic culture conditions. J Clin Microbiol 52:3259-3263. DOI: 10.1128/JCM.0079314

31. UK Standards for Microbiology Investigations (2014). Processing of faeces for Clostridium difficile; Bacteriology B10, Issue no. 15.London: Standards Unit, Microbiology Services, Public Health England.

32. Maturin L, Peeler JT. 2001. Bacteriological Analytical Manual (BAM) - BAM: Aerobic Plate Count. FDA Bacteriol Anal Man Chapter 3. https://www.fda.gov/Food/FoodScienceResearch/LaboratoryMethods/ucm063 346.htm. Last accessed: 10/04/2018

33. Nadkarni M, Martin FE, Jacques NA, Hunter N. 2002. Determination of bacterial load by real-time PCR using a broad range (universal) probe and primer set. Microbiology 148:257-266. DOI: 10.1099/00221287-148-1-257 
480 34. Stubbs SLJ, Brazier JS, O’Neill GL, Duerden BI. 1999. PCR targeted to the

481

482

483

484

485

486

487

488

489

490

491

492

493

494

495

496

497

498

499

500

501

502

503

504

16S-23S rRNA gene intergenic spacer region of Clostridium difficile and construction of a library consisting of 116 different PCR ribotypes. J Clin Microbiol 37:461-463. PMID: 9889244

35. Luna RA, Boyanton BL, Mehta S, Courtney EM, Webb CR, Revell PA, Versalovic J. 2011. Rapid stool-based diagnosis of Clostridium difficile infection by real-time PCR in a children's hospital. J Clin Microbiol 49:851-857.

DOI: $10.1128 / J C M .01983-10$

36. Shibayama K, Nagasawa M, Ando T, Minami M, Wachino JI, Suzuki S, Arakawa Y. 2006. Usefulness of adult bovine serum for Helicobacter pylori culture media. J Clin Microbiol 44:4255-4257. DOI: 10.1128/JCM.00477-06

37. Soltis RD, Hasz D, Morris MJ, Wilson ID. 1979. The effect of heat inactivation of serum on aggregation of immunoglobulins. Immunology 36:37-45. PMID: 422227

38. Blodgett R. 2010. Bacteriological Analytical Manual (BAM) - BAM Appendix 2: Most Probable Number from Serial Dilutions. FDA Bacteriol Anal Man 1-27. https://www.fda.gov/Food/FoodScienceResearch/LaboratoryMethods/ucm109 656.htm. Last accessed: 10/04/2018

39. Thitaram SN, Frank JF, Siragusa GR, Bailey JS, Dargatz DA, Lombard JE, Haley CA, Lyon SA, Fedorka-Cray PJ. 2016. Antimicrobial susceptibility of Clostridium difficile isolated from food animals on farms. Int $\mathrm{J}$ Food Microbiol 227:1-5. DOI: 10.1016/j.ijfoodmicro.2016.03.017

40. Dharmasena M, Jiang X. 2018. Improving culture media for the isolation of Clostridium difficile from compost. Anaerobe 51:1-7. DOI:

10.1016/j.anaerobe.2018.03.002 
505

506

507

508

509

510

511

512

41. Wilson KH, Kennedy MJ, Fekety FR. 1982. Use of sodium taurocholate to enhance spore recovery on a medium selective for Clostridium difficile. J Clin Microbiol 15:443-446. PMID: 7076817

42. Jhung MA, Thompson AD, Killgore GE, Zukowski WE, Songer G, Warny M, Johnson S, Gerding DN, McDonald LC, Limbago BM. 2008. Toxinotype V Clostridium difficile in humans and food animals. Emerg Infect Dis 14:1039_ 1045. DOI: $10.3201 /$ eid1407.071641

43. Zidaric V, Beigot S, Lapajne S, Rupnik Maja M. 2010. The occurrence and high diversity of Clostridium difficile genotypes in rivers. Anaerobe 16:371375. DOI: 10.1016/j.anaerobe.2010.06.001

44. Janezic S, Zidaric V, Pardon B, Indra A, Kokotovic B, Blanco J, Seyboldt C, Diaz C, Poxton IR, Perreten V, Drigo I, Jiraskova A, Ocepek M, Weese J, Songer J, Wilcox MH, Rupnik M. 2014. International Clostridium difficile animal strain collection and large diversity of animal associated strains. BMC Microbiol 14:173. DOI: 10.1186/1471-2180-14-173

45. Esfandiari Z, Jalali M, Ezzatpanah H, Weese JS, Chamani M. 2014. Prevalence and characterization of Clostridium difficile in beef and mutton meats of Isfahan Region, Iran. Jundishapur J Microbiol 7:1-5. DOI: $10.5812 / \mathrm{jjm} .16771$

46. Anand C, Gordon R, Shaw H, Fonseca K, Olsen M. 2000. Pig and goat blood as substitutes for sheep blood in blood-supplemented agar media. J Clin Microbiol 38:591-594. PMID: 10655351

47. Greenwood D, Slack RCB, Peutherer JF. 1997. Medical Microbiology: A Guide to Microbial Infections: Pathogenesis, Immunity, Laboratory Diagnosis and Control. 15th Edition, Churchill Livingstone, London. 
48. Corry JEL, Curtis GDW, Baird RM. 2011. Handbook of Culture Media for Food and Water Microbiology- Third edition. RSC Publishing.

49. Lister M, Stevenson E, Heeg D, Minton NP, Kuehne SA. 2014. Comparison of culture based methods for the isolation of Clostridium difficile from stool samples in a research setting. Anaerobe 28:226-229. DOI: 10.1016/j.anaerobe.2014.07.003

50. Hopman NEM, Keessen EC, Harmanus C, Sanders IMJG, van Leengoed LAMG, Kuijper EJ, Lipman LJA. 2011. Acquisition of Clostridium difficile by piglets. Vet Microbiol 149:186-192. DOI: 10.1016/j.vetmic.2010.10.013

51. Loo VG, Brassard P, Miller MA. 2016. Household Transmission of Clostridium difficile to Family Members and Domestic Pets. Infect Control Hosp Epidemiol 37:1-7. DOI: 10.1017/ice.2016.178

52. Esfandiari Z, Weese S, Ezzatpanah H, Jalali M, Chamani M. 2014. Occurrence of Clostridium difficile in seasoned hamburgers and seven processing plants in Iran. BMC Microbiol 14:283. DOI: 10.1186/s12866-014-0283-6

53. Bakri MM, Brown DJ, Butcher JP, Sutherland AD. 2009. Clostridium difficile in Ready-to-Eat Salads, Scotland. Emerg Infect Dis 15:817-818. DOI: 10.3201/eid1505.081186

54. Davies KA, Longshaw CM, Davis GL, Bouza E, Barbut F, Barna Z, Delmée M, Fitzpatrick F, Ivanova K, Kuijper E, Macovei IS, Mentula S, Mastrantonio P, von Müller L, Oleastro M, Petinaki E, Pituch H, Norén T, Nováková, E, Nyč O, Rupnik M, Schmid D, Wilcox MH. 2014. Underdiagnosis of Clostridium difficile across Europe: The European, multicentre, prospective, biannual, pointprevalence study of Clostridium difficile infection in hospitalised patients with diarrhoea (EUCLID). Lancet Infect Dis 14:1208-1219. DOI: 10.1016/S1473- 
$3099(14) 70991-0$

556 Table 1: Recommended supplementation of CCFB and CDMN

557

\begin{tabular}{llll}
\hline & $\begin{array}{l}\text { Sodium } \\
\text { taurocholate } \\
\text { concentration }(\mathrm{T})\end{array}$ & $\begin{array}{l}\text { Horse blood } \\
\text { concentration } \\
(\mathbf{H B}) \mathbf{( \% )}\end{array}$ & \\
Media & $\mathbf{( \% )}$ & $\mathrm{NA}^{*}$ & References \\
\hline CCFB & $\mathrm{NA}$ & $\mathrm{NA}^{*}$ & $(26)$ \\
CCFB-T & 0.1 & 7 & $(25)$ \\
CDMN & 0.1 & $\mathrm{NA}$ & $(45)$ \\
CDMN-T & 0.1 & 7 & $(17)$ \\
CDMN-HB & $\mathrm{NA}$ & 7 & $(26)$ \\
CDMN-THB & 0.1 & & $(17,26)$ \\
\hline
\end{tabular}

558

559

${ }^{*}$ CCFB contains 7\% (v/v) horse blood as prepared.

560

561

562

563

564

565

566

567

568

569

570

571

572

573

574

575

576 


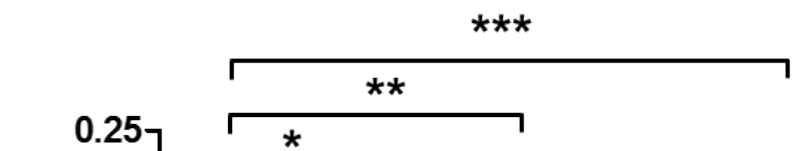

581

582

583

584

585

586

587

588

589

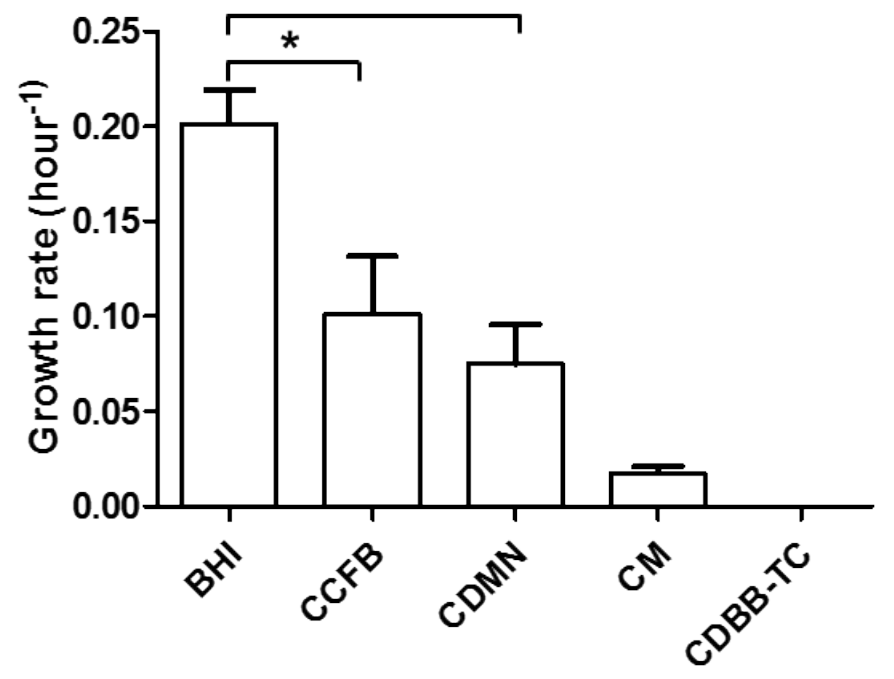

590

591 Figure 1: Growth rate of $C$. difficile M120 in each BHI, CCFB, CDMN, CM and

592 CDBB-TC incubated anaerobically at $37^{\circ} \mathrm{C}$ for $33 \mathrm{~h} ;{ }^{*} p<0.05,{ }^{* *} p<0.01,{ }^{* * *} p<0.001$. 593

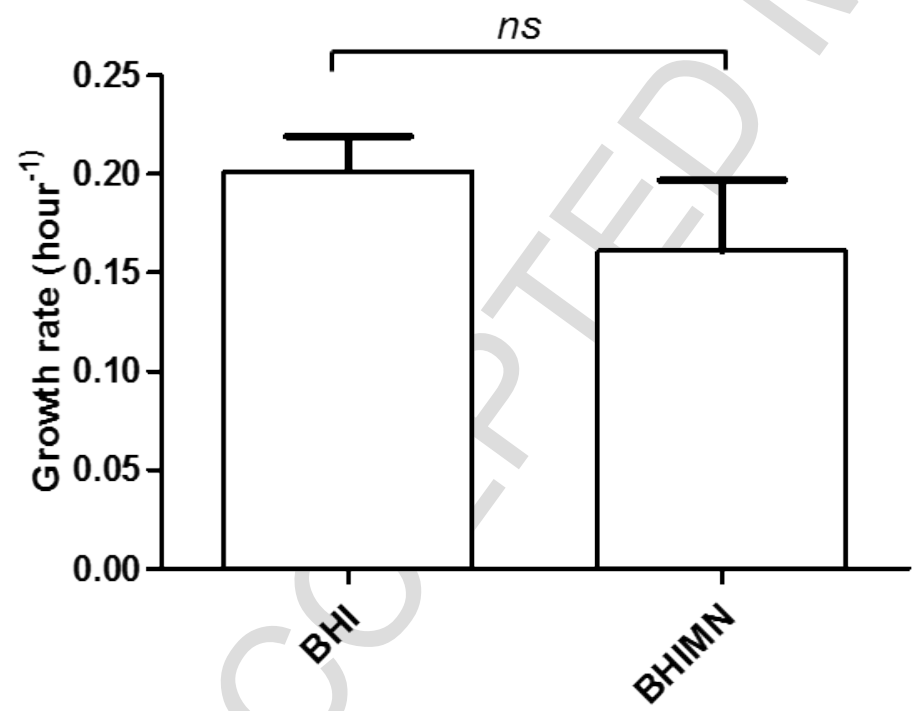

594

595 Figure 2: Growth of $C$. difficile M120 in BHI and BHIMN incubated anaerobically at $59637^{\circ} \mathrm{C}$ for $33 \mathrm{~h}$. 
600

601

602

603

604

605

606

607

608

609

610

611

612

613

614

615

616

617

618

619

620

621

622

623

624

625

626

627

628

629
Sodium taurocholate concentration (\%)

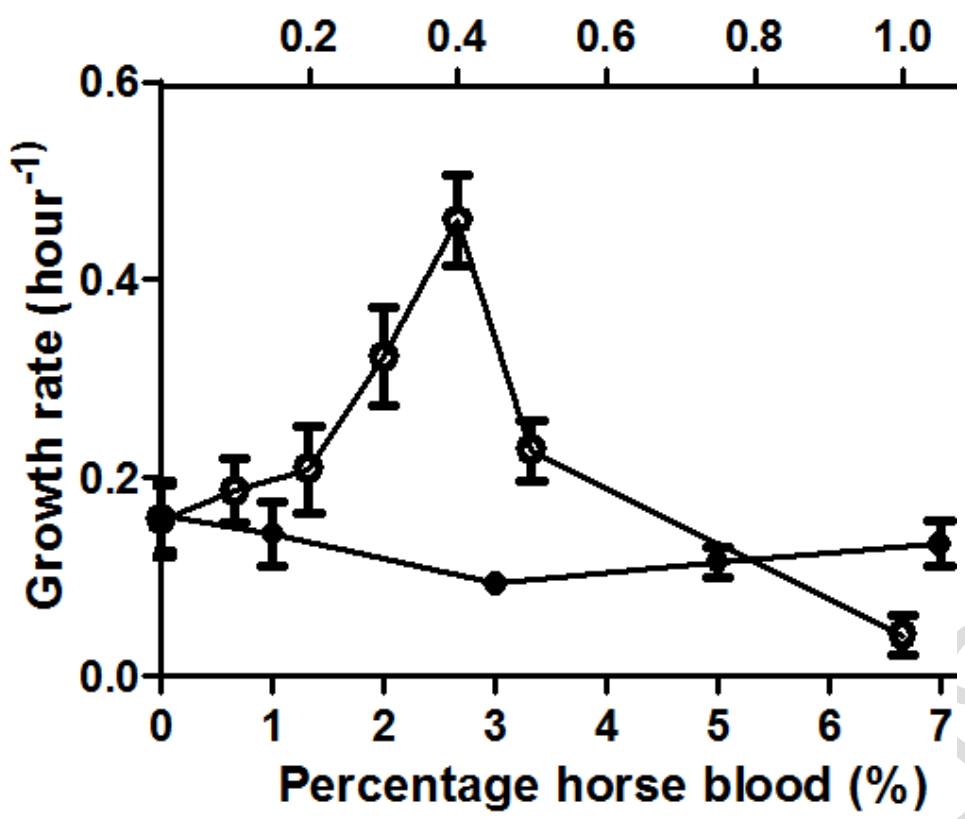

Figure 3: Growth of $C$. difficile M120 with varying concentrations of sodium taurocholate, 0-1\% (o), or defibrinated horse blood in BHIMN, 0-7\% (•).

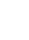


630

631

632

633

634

635

636

637

638

639

640

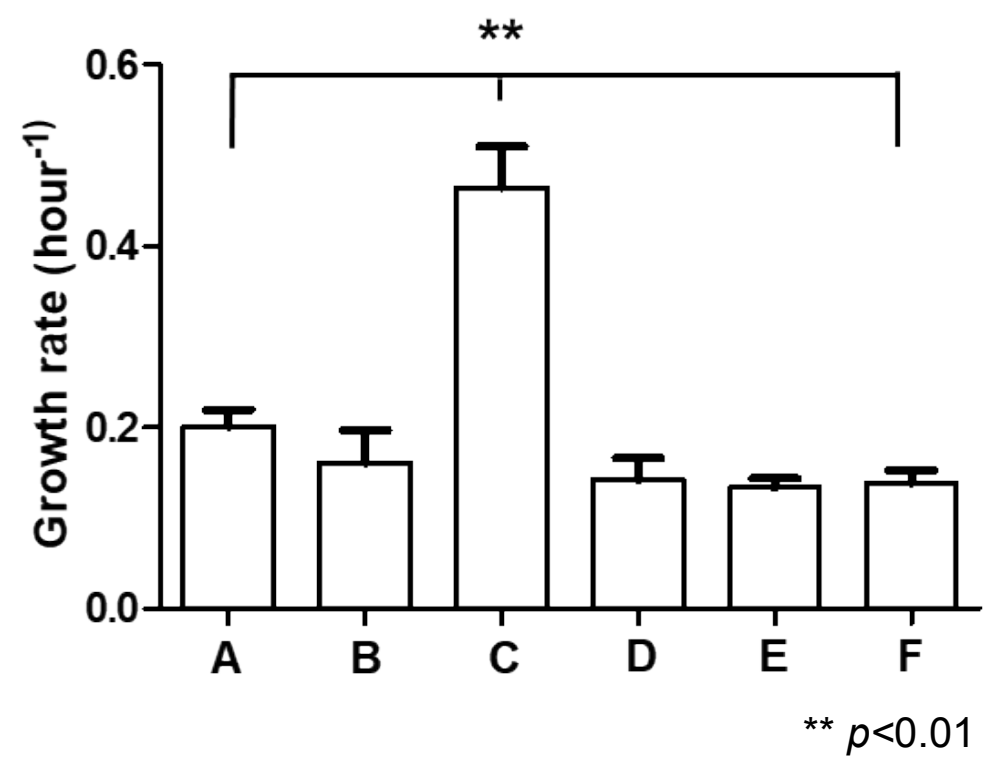

641

642

Figure 4: Growth rates of $C$. difficile $\mathrm{M} 120$ in $\mathbf{A}) \mathbf{B H I}$ - without supplementation, B)

643 BHIMN - BHI supplemented with antibiotics, moxalactam (32 $\mu \mathrm{g} / \mathrm{ml})$ and norfloxacin

$644(12 \mu \mathrm{g} / \mathrm{ml})$, C) BHIMN-T - BHI supplemented with moxalactam $(32 \mu \mathrm{g} / \mathrm{ml})$,

645 norfloxacin $(12 \mu \mathrm{g} / \mathrm{ml})$ and $0.4 \%$ (w/v) sodium taurocholate, D) BHIMN-HB - BHI

646 supplemented with moxalactam $(32 \mu \mathrm{g} / \mathrm{ml})$, norfloxacin $(12 \mu \mathrm{g} / \mathrm{ml})$ and $7 \%(\mathrm{v} / \mathrm{v})$ defibrinated horse blood.

E) BHIMN-HB (heat) - BHI supplemented with moxalactam (32 $\mu \mathrm{g} / \mathrm{ml})$, norfloxacin $(12 \mu \mathrm{g} / \mathrm{ml})$ and $7 \%(\mathrm{v} / \mathrm{v})$ defibrinated horse blood which has been heat treated to inactivate complement, F) BHIMN-THB - BHI supplemented with moxalactam $(32 \mu \mathrm{g} / \mathrm{ml})$, norfloxacin $(12 \mu \mathrm{g} / \mathrm{ml})$, and $0.1 \%(\mathrm{w} / \mathrm{v})$ sodium taurocholate and $7 \%(\mathrm{v} / \mathrm{v})$ defibrinated horse blood. 
663

664

665

666

667

668

669

670

671

672

673

674

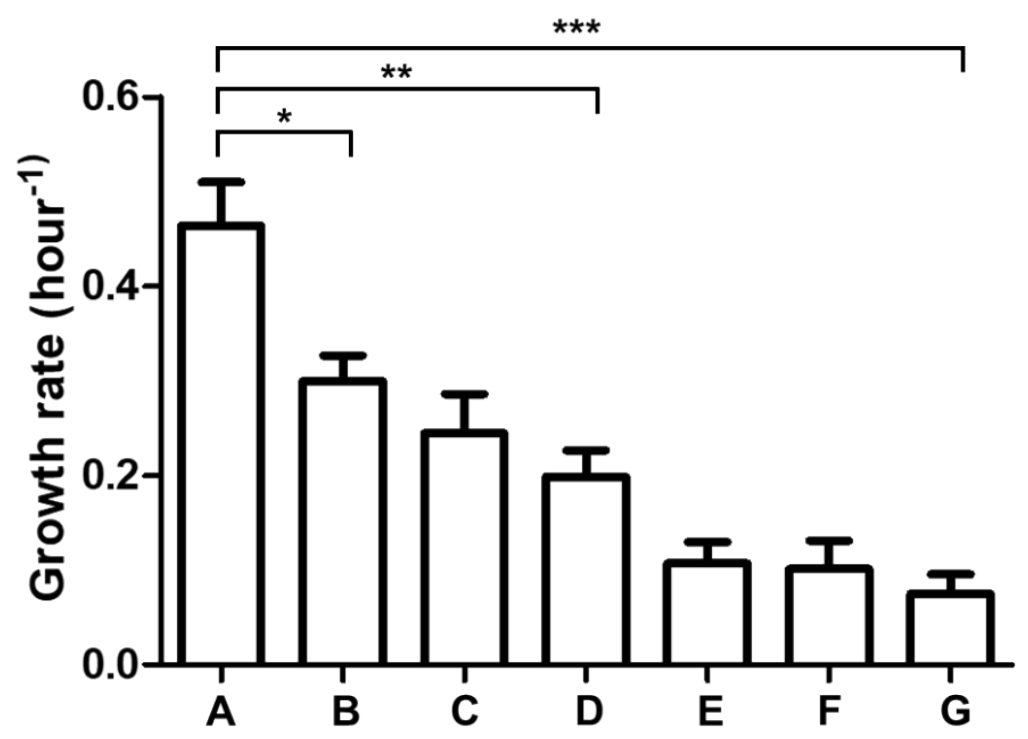

675

Figure 5: Specific growth rate for $C$. difficile M120 in A) BHIMN-T, B) CCFB-T- as

676

prepared by Arroyo et al. (25) C) CDMN-HB as prepared by Aspinall and

677 Hutchinson(26), D) CDMNT - as prepared by Xu et al.(17), E) CDMN-THB (17, 26),

678

F) CCFB - as prepared by Aspinall and Hutchinson (26),

G) CDMN - as prepared by

679

Esfandiari et al. (45); ${ }^{*} p<0.05,{ }^{* *} p<0.01,{ }^{* * *} p<0.001$.

680

681

682

683

684

685

686

687

688

689

690

691

692

693

694 
695 Table 2: Summary of specific growth rate of $C$. difficile M120 and corresponding lag 696 phase in each medium

697

\begin{tabular}{llll}
\hline Media & $\begin{array}{l}\text { Lag phase } \\
\text { (hours) }\end{array}$ & $\begin{array}{l}\text { Growth rate } \\
\text { (hour }^{-1} \text { ) }\end{array}$ & SEM \\
\hline BHIMNT & $<14$ hours & 0.465 & 0.045 \\
CCFB-T & $\sim 24$ hours & 0.300 & 0.027 \\
CDMN-HB & $\sim 18$ hours & 0.245 & 0.041 \\
CDMN-T & $\sim 15$ hours & 0.199 & 0.028 \\
CDMN-THB & $\sim 14$ hours & 0.107 & 0.022 \\
CCFB & $\sim 27$ hours & 0.102 & 0.030 \\
CDMN & $\sim 33$ hours & 0.075 & 0.021 \\
\hline
\end{tabular}

698

699

700

701

702

703 
704 Table 3: Evaluation of the optimum concentration of sodium taurocholate in $C$. difficile spore recovery across representative

705 isolates from clades $1-5$, using estimation of MPN/ml

706

Number of positives at each dilution factor

Confidence limits

\begin{tabular}{|c|c|c|c|c|c|c|c|c|}
\hline $\begin{array}{l}\text { Isolate } \\
\text { (Clade) }\end{array}$ & & $-4^{a}$ & $-5^{b}$ & $-6^{c}$ & $\begin{array}{l}\text { Reported } \\
\text { positives }\end{array}$ & MPN/ml & Lower & Upper \\
\hline \multirow[t]{2}{*}{ TL178 (1) } & $0.4 \%$ sodium taurocholate & $12 / 14$ & $6 / 14$ & $1 / 14$ & $12-6-1$ & $2.83 \times 10^{4}$ & $1.7 \times 10^{4}$ & $4.9 \times 10^{4}$ \\
\hline & No sodium taurocholate & $4 / 14$ & $0 / 14$ & $0 / 14$ & $0-0-0$ & $2.98 \times 10^{3}$ & $1.1 \times 10^{3}$ & $8.0 \times 10^{3}$ \\
\hline \multirow[t]{2}{*}{ R20291 (2) } & $0.4 \%$ sodium taurocholate & $11 / 14$ & $9 / 14$ & $5 / 14$ & $11-9-5$ & $3.72 \times 10^{4}$ & $2.3 \times 10^{4}$ & $5.9 \times 10^{4}$ \\
\hline & No sodium taurocholate & $4 / 14$ & $0 / 14$ & $0 / 14$ & $4-0-0$ & $2.97 \times 10^{3}$ & $1.1 \times 10^{3}$ & $8.0 \times 10^{3}$ \\
\hline \multirow[t]{2}{*}{ CD305 (3) } & $0.4 \%$ sodium taurocholate & $14 / 14$ & $3 / 14$ & $1 / 14$ & $14-3-1$ & $3.80 \times 10^{4}$ & $2.0 \times 10^{4}$ & $7.4 \times 10^{4}$ \\
\hline & No sodium taurocholate & $4 / 14$ & $0 / 14$ & $0 / 14$ & $4-0-0$ & $2.98 \times 10^{3}$ & $1.1 \times 10^{3}$ & $8.0 \times 10^{3}$ \\
\hline \multirow[t]{2}{*}{ CF5 (4) } & $0.4 \%$ sodium taurocholate & $12 / 14$ & $5 / 14$ & $2 / 14$ & $12-5-2$ & $2.80 \times 10^{4}$ & $1.6 \times 10^{4}$ & $4.8 \times 10^{4}$ \\
\hline & No sodium taurocholate & $3 / 14$ & $0 / 14$ & $0 / 14$ & $3-0-0$ & $2.14 \times 10^{3}$ & $6.9 \times 10^{2}$ & $6.7 \times 10^{3}$ \\
\hline \multirow[t]{2}{*}{ M120 (5) } & $0.4 \%$ sodium taurocholate & $13 / 14$ & $8 / 14$ & $2 / 14$ & $13-8-2$ & $5.0 \times 10^{4}$ & $2.2 \times 10^{4}$ & $6.1 \times 10^{4}$ \\
\hline & No sodium taurocholate & $6 / 14$ & $0 / 14$ & $0 / 14$ & $6-0-0$ & $4.9 \times 10^{3}$ & $2.2 \times 10^{3}$ & $1.1 \times 10^{4}$ \\
\hline
\end{tabular}

$707 \quad$ a1 $\times 10^{-4}$ dilution is representative of $130 \pm 3$ spores $/ \mathrm{ml}$

$708 \mathrm{~b} 1 \times 10^{-5}$ dilution is representative of $13 \pm 0.3 \mathrm{spores} / \mathrm{ml}$

$709{ }^{c} 1 \times 10^{-6}$ dilution is representative of $1.3 \pm 0.03$ spores $/ \mathrm{ml}$ 


\section{Highlights}

2 i. Comparison of enrichment media using qPCR to monitor growth of $C$. difficile.

3 ii. $0.4 \%$ sodium taurocholate provided optimum growth in Brain Heart Infusion

$4 \quad(\mathrm{BHI})$ supplemented with moxalactam and norfloxacin (BHIMN-T) when

5 compared to other media with recommended supplementation.

6 iii. BHIMN-T provided effective for the recovery of spores at low concentrations. 